\title{
MRS Council Meets in Boston
}

The Council of the Materials Research Society met on December 1-2 during the 1989 MRS Fall Meeting in Boston, Massachusetts. The following report highlights the plans and actions of that meeting.

\section{Finance}

Council approved the preliminary 1990 budget of approximately $\$ 4.1$ million for the Society. This is nearly $30 \%$ larger than the 1989 budget, reflecting the dynamism and growth of the Society both in numbers and in activities.

\section{Program}

One of the clearest manifestations of the vitality of MRS is in its meetings. The 1989 Fall Meeting was the largest ever, with over 3,900 registrants. Innovations which were pioneered at this meeting included a video link between hotels for selected symposia and the national broadcast of one day of Symposium $X$. Both experiments were successful, and Council authorized their continuation in 1990.

Desire to limit the growth in size of the MRS Spring and Fall meetings as well as recognition of the special benefits offered by smaller conferences has led MRS to plan three stand-alone meetings over the next 18 months. The 2nd International Conference on Electronic Materials and the Conference on New Diamond Science and Technology are scheduled for September 1990. A symposium on high $T_{c}$ superconductor thin films will be held in conjunction with the forum of the Solid State Sciences Committee of the National Research Council in February 1991.

\section{External Affairs}

Council approved two new initiatives concerning relationships between MRS and other bodies. The first of these authorizes MRS representation on an Ad Hoc Committee on a "Materials Institute" concept. The committee will define the scope, purpose and membership of such a "Materials Institute" and issue a report to the various scientific societies represented on the committee. No commitment on the part of MRS or any other society to participation beyond such discussion is implied by representation on the committee.

The External Affairs Committee of MRS was authorized to form an ad hoc implementation task group to advise MRS Council on appropriate mechanisms to pursue activities on behalf of MRS related to information flow to and from the federal government and other sources. MRS will rent office space in Washington, DC for one year which it will use for meetings of this task group. The group will function for about one year. During this period it will define the goals and scope of appropriate MRS activities in Washington, identify the mechanism for carrying out these activities, define personnel needs, and develop a three-year plan. The group will issue a progress report to Council at its April 1990 meeting; the final report will be issued in December 1990.

\section{Awards}

Council adopted several motions pertaining to the MRS awards program, creating two new classes of awards and the means for funding them. The Outstanding Young Investigator Award will recognize outstanding, interdisciplinary scientific work in materials research by a young scientist or engineer. The awardee must show exceptional promise as a developing leader in the materials area. The first such award will be offered for presentation at the 1991 MRS Spring Meeting.

MRS Medals are intended to constitute public and professional recognition of outstanding recent achievements in materials research. A Medal will be awarded for a specific discovery or advancement which is expected to have a major impact on the progress of any materials-related field. The first Medals will be offered in 1990, when no more than two will be awarded.

Council also established an Awards Endowment Fund which will be sustained by contributions solicited for the purpose. Investment yield from the Fund will be used to support specific awards programs, as designated by Council. The Young Investigator Award and the Medalist Program will be so funded.

\section{Membership}

The Materials Research Society continues to experience significant growth in membership. Nearly 1,000 members have been added to the ranks over the past year, raising the total membership to nearly 9,200 . Increasing activity at the local level led to establishment by Council of a new University Chapter at the Stevens Institute of Technology and a new local Section in the Greater Pittsburgh Area.

Julia M. Phillips

Secretary, Materials Research Society

\section{Just PUBLISHED by MRS}

\section{Tungsten and Other Advanced Metals for VLSI/ULSI Applications V}

Proceedings of the 1989 workshops held September 20-21 in San Mateo, California (sponsored by Continuing Education in Engineering, University of California, Berkeley) and October 19-20 in Tokyo, Japan (sponsored by the Japan Society of Applied Physics).

Summarizes the latest results in the understanding of surface reactions, modeling of reactor and deposition kinetics, development of blanket and selective tungsten deposition processes, and characterization of tungsten films, plus rapid developments in other CVD metals such as copper and aluminum.

Editors: S.S. Wong, Stanford University; S. Furukawa, Tokyo Institute of Technology

Tungsten and Other Advanced Metals for VLSI/ULSI Applications 1990, hardcover or microfiche, 50 papers, 427 pages.

ISBN: 1-55899-068-2

Order Code: V-5B

(V-5B-F for microfiche)

\$45 MRS Members

$\$ 52$ U.S. List \$59 Foreign

Also available: Tungsten and Other Refractory Metals for VLSI Applications, Volumes I through IV.

Save by enrolling in the MRS Standing Order Plan for this series!

Order from MRS, Publications Department, 9800 McKnight Road, Pittsburgh, PA 15237; telephone (412) 367-3012; fax (412) 3674373. In Europe, Africa and the Middle East, contact Clarke Associates at the address on $p .44$ of this issue. 